\title{
B Subgroup: Bx blood Group in a Patient : A Case Report
}

\author{
Ayesha Khatun ${ }^{1}$, Jolly Biswas ${ }^{2}$, Munshi Md. Habibullah ${ }^{3}$, Ashadul Islam $^{4}$, Nittyananda Shill $^{5}$, Atiar Rahman $^{6}$, \\ Sheikh Saiful Islam Shaheen ${ }^{7}$ \\ ${ }^{1}$ Associate Professor, Dept. of Transfusion Medicine, BSMMU, Dhaka, ${ }^{2}$ Professor and Head, Dept. of Transfusion Medicine, BSMMU, \\ Dhaka, ${ }^{3}$ Assistant Professor and Head, Dept. of Transfusion Medicine, Sir Salimullah Medical College \& Mitford Hospital, Dhaka, \\ ${ }^{4}$ Associate Professor, Dept. of Transfusion Medicine, BSMMU, Dhaka, ${ }^{5}$ Associate Professor, Dept. of Transfusion Medicine, BSMMU, \\ Dhaka, ${ }^{6}$ Medical Officer, Dept. of Transfusion Medicine, BSMMU, Dhaka, ${ }^{7}$ Program Officer, Dept. of Transfusion Medicine, BSMMU, \\ Dhaka.
}

\begin{abstract}
:
This is a report of a case of B Sub Group: $\mathrm{B}_{\mathrm{x}}$, first ever detected in Bangladesh, while doing compatibility test of a sample of a patient undergoing cardiac surgery. The patient was referred to the transfusion medicine department of Bangabandhu Sheikh Mujib Medical University to do cross-match with 8 proposed donors of same ABO group prior to cardiac surgery. His red cells showed weak agglutination with anti-B, anti-AB and in his serum there was potent Anti-A and weak anti-B which was not detected at $37^{\circ} \mathrm{C}$. After adsorption with anti-B an elute was prepared from patient's cells which agglutinate with $\mathrm{B}$ and $\mathrm{AB}$ cells but did not agglutinate with $\mathrm{A}$ or $\mathrm{O}$ cells. The patient could be transfused with $\mathrm{B}$ blood but in this situation of cardiac surgery, as he should have to be kept in hypothermic condition, we transfused him with $\mathrm{O}$ washed red cell with $\mathrm{AB}$ plasma during operation. Patient was released from hospital without any complication. The weak B subgroups are: $\mathrm{B}_{3}, \mathrm{~B}_{\mathrm{x}} \& \mathrm{~B}_{\mathrm{el}}$. $\mathrm{B}_{3}$ shows a mixed field of agglutination with anti $\mathrm{B}$. $\mathrm{B}_{\mathrm{x}}$ shows a weak agglutination and weak anti- $\mathrm{B}$ is found in the serum. $\mathrm{B}_{\mathrm{el}}$ is not agglutinated with anti-B but is only adsorbed anti-B. With meticulous attention, cell \& serum grouping of recipient and proposed donor/s to be done along with 3 phase cross-matching (Saline phase at room temp, at 4 and 37 degree Celsius temp, Indirect Coomb's Test phase) to ensure right blood to the right patient at right time.
\end{abstract}

Keywords: $\mathrm{ABO}$ blood grouping, sub-groups $\mathrm{B}_{\mathrm{x}}$, problems of $\mathrm{RBC}$ phenotype.

[BSMMU J 2012; 5(1):81-82]

\section{Introduction:}

The ABO blood group system is the very first human blood grouping system that remains the most important in transfusion practice. This is because of the regular occurrence of the antibodies; Anti-A, anti-B \& anti-AB, reactive at $37^{\circ} \mathrm{C}$ and capable to cause red cell destruction in persons whose red cells lack the corresponding antigens. ${ }^{1} \mathrm{~B}_{\mathrm{x}}$ (subgroup of $\mathrm{B}$ ) is a very rare phenotype of blood. It is wrongly typed as ' $\mathrm{O}$ ' because the $\mathrm{B}$ antigen is very weakly present on red cell membrane, which can not be detected if weak anti-B is used in cell typing. Most of the $\mathrm{ABO}$ blood groups antibodies are $1 \mathrm{gM}$ in nature and detected best at $4^{\circ} \mathrm{C}$. Most of the laboratories are doing blood groups only by forward grouping and these results are not counter checked by doing reverse grouping. Moreover, they perform grouping in slide method in which weak antigens are not detected and as a result the persons are typed wrongly There is no subgroup of B analogous to subgroup $A_{2}$ but various types of reacting weakly or not at all with anti-B have been described. Salman in 1976

Address for Correspondence: Dr. Ayesha Khatun, Associate Professor, Dept. of Transfusion Medicine, BSMMU, Dhaka proposed that the weak $\mathrm{B}$ should be used as follows: $\mathrm{B}_{3}$, $\mathrm{B}_{\mathrm{x}} \& \mathrm{~B}_{\mathrm{el}} \cdot \mathrm{B}_{3}$ shows a mixed field of agglutination with anti B. $B_{x}$ shows a weak agglutination and weak anti-B is found in the serum and his saliva inhibits the reaction between anti-B and $B$ cells. $B_{\text {el }}$ are not agglutinated with anti-B only adsorbed anti-B. ${ }^{2,3}$

In the routine determination of $\mathrm{ABO}$ blood groups, anti$\mathrm{A}$, anti-B and anti-AB are used for testing red cells for $\mathrm{A}$ and $\mathrm{B}$ antigens. The group is checked in serum or reverse grouping by testing the serum against known $\mathrm{A}, \mathrm{B}$ \& $\mathrm{O}$ red cells. We are reporting a case of B subgroup: Bx first ever detected in Bangladesh.

\section{Case Report:}

A 46-year-old man was admitted in the cardiac surgery ward of Bangabandhu Sheikh Mujib Medical University (BSMMU) for surgical repair of Aortic valvular disease. Before operation, his blood group was identified as $\mathrm{O}+\mathrm{ve}$ (positive). On the day before operation, 8 donors of $\mathrm{O}+\mathrm{ve}$ (positive) came with patient's sample for cross-matching, screening etc. During cross matching, his sample was found incompatible with all the donors. Then we gave special attention in doing his $\mathrm{ABO}$ grouping. 
Table-I

Antibodies and antigens found in patient's sample

\begin{tabular}{ccccccc}
\hline Anti-B & Anti-A & Anti-AB & A cell & B cell & O cell & Auto control \\
\hline+ & - & ++ & $+1+$ & + & - & - \\
\hline
\end{tabular}

(NB: Table-I revealed in forward grouping - B group and reverse grouping - O group)

During cross-matching with $\mathrm{B}+\mathrm{ve}$ and B-ve donors, we could detect that the sample had major incompatibility at room temperature and $4^{\circ} \mathrm{C}$ but not at $37^{\circ} \mathrm{C}$. His saliva inhibited the reaction of anti-B with $\mathrm{B}$ cells. So we then realized that his blood group was $B_{x}$ that contains weak anti-B too. After adsorption with anti-B an elute was prepared from patient's cells which agglutinated with $B$ and $\mathrm{AB}$ cells but did not agglutinate with $\mathrm{A}$ or $\mathrm{O}$ cells.

Elutes agglutinated with $\mathrm{B}$ and $\mathrm{AB}$ red cells did not agglutinate with A or O cells. B substance was present in his saliva, which inhibited the reaction between anti-B and $B$ cells. We then advised to transfuse the patient with O washed red cell with AB plasma. All seven siblings' of the patient had blood group B+ve, the parents' blood groups could not be explored.

Table-II

Antigens and antibodies present in B blood group

\begin{tabular}{lccc}
\hline Group & Sub-group & $\begin{array}{c}\text { Antigens on } \\
\text { red cell }\end{array}$ & $\begin{array}{c}\text { Antibodies } \\
\text { in serum }\end{array}$ \\
\hline $\mathrm{B}$ & $\mathrm{B}_{3} \mathrm{~B}_{\mathrm{x}} \mathrm{B}_{\mathrm{el}}$ & $\mathrm{B}$ & Anti-A, Anti-B* \\
\hline
\end{tabular}

*(weak, rare and usually cold)

\section{Discussions:}

ABO subgroups are phenotypes those differ in amount of antigens carried on red cells and for secretors soluble antigens present in the saliva. Subgroups of A are more commonly encountered than subgroups of B (AABB technical manual). There is no subgroup of $B$ analogous to subgroup $A_{2}$ but various types of reacting weakly or not at all with anti-B have been described. Salman in 1976 proposed that the weak B should be used as follows: $\mathrm{B}_{3}, \mathrm{~B}_{\mathrm{x}} \& \mathrm{~B}_{\mathrm{el}}$.

Subgroups are characterized by decreasing numbers of antigen sites on the red cells and the reciprocal increase in $\mathrm{H}$ antigen activity. ${ }^{5,6}$ Subgroups are more often recognized when there is a discrepancy between the red cells and serum grouping. Most of the laboratories are doing blood groups only by forward grouping; these results are not checked by doing Reverse grouping. Moreover, they perform grouping in slide method in which weak antigens are not detected and as a result the persons are typed wrongly.

\section{Conclusions:}

Usually subgroups are wrongly typed as O, which may cause HTR (Hemolytic Transfusion reaction), leading to death. ${ }^{8,9,10} \mathrm{~B}_{3}$ shows a mixed field of agglutination with anti $B$. $B_{x}$ shows a weak agglutination and weak anti-B is found in the serum. $B_{\text {el }}$ cells are not agglutinated with anti-B only absorbed anti-B. ${ }^{11,12}$

Meticulous attention to cell \& serum grouping of recipient and proposed donor/s to be done along with 3 phase cross-matching (Saline phase at room temp, 4 and 37 degree Celsius temp, ICT phase) to ensure right blood to the right patient at right time.

\section{Acknowledgments:}

The author would like to acknowledge with great honor and respect the patient, his family, physicians and all the personnel of the Department of Transfusion Medicine of BSMMU.

\section{References:}

1. Sherman M, Bain V, Villeneuve JP. The management of chronic viral hepatitis: A Canadian consensus conference 2004. Can J Gastro Enteral 2004; 18: 715-28

2. Brown KE, Hibbs JR, Gallinella G. Resistance to parvovirus B19 infection due to lack of virus receptor (erythrocyte $p$ antigen). N Eng J Med 1994; 330: 1192-6.

3. Haataja S, Tikkanen K, Liukkonen J. Characterization of a novel Bacterial adhesion specificity of a streptococcus suis recognizing blood group P receptor oligosaccharides. J Biol Chem 1993; 268: 4311-17

4. Spitalnic PF and Spitalnic SL. The P Blood Group System: Biochemical, Serological and Clinical aspects. Transfuse Med Rev 1995; 9: 110-22.

5. Kennedy MS, Waheed A, Moor J. ABO discrepancy with monoclonal $\mathrm{ABO}$ reagents caused by ph dependent autoantibody. Immuno-Haematology 1995; 11: 71-3.

6. Mollison PL, Engelfriet CP, Contrera M. Blood Transfusion in Clinical Medicine. $10^{\text {th }}$ ed Oxford: Blackwell Scientific Publication 1997; 114-117.

7. Silva MA. Standards for Blood Banks and Transfusion Services, $23^{\text {rd }}$ edition Bethesda MD; AABB 2005; 293-294.

8. Oriol R, Candelier JJ, Mollicon R. Molecular Gecetics of H. Vox Sang 2000; 78(suppl 2): 105-8.

9. Daniel G. Human Blood Groups, 2nd ed Oxford: Blackwell Science 2002; 7-67.

10. Yamamoto F, Clusen H, White T. Molecular Genetic basis of the Histo-Blood Group ABO System. Nature 1990; 345: 229-33.

11. Lee AH and Reid ME. ABO Blood Group System: A Review of Molecular aspects. Immuno-Haematology 2000; 16: 1-6.

12. Watkins WM. The ABO Blood Group System: Historical Background. Transfus Med 2001; 11: 243-65. 